\title{
Taxonomic Review of families Botryococcaceae and Characiaceae, Order Chlorococcales, and Class Chlorophyceae in Korea
}

\author{
Yong Jae Kim* \\ Department of Life Science, Daejin University, Pocheon 487-711, Korea
}

\begin{abstract}
A study on Chlorococcal algae was carried out at 21 stations (ponds, swamps, reservoirs, lakes and rivers) from May 2011 to January 2012. The families of Botryococcaceae and Characiaceae of Chlorococcales were investigated to the extent of 8 genera, 20 species. Among them, 10 taxa are newly recorded in algal flora of Korea by Kim and Kim (2012) and this study reviewed about ; 1) Family Botryococcaceae: Dictyosphaerium elegans, D. reniforme, D. simplex, D. elongatum, 2) Family Characiaceae: Characium conicum, Ankyra ancora, A. judayi, A. calcarifera, Schroederia spiralis, S. indica.
\end{abstract}

Key words: Botryococcaceae, Characiaceae, Chlorococcal algae, Chlorococcales, Korea, newly recorded

\section{INTRODUCTION}

Freshwater green algae are characterized by having high species diversity (John 1994). The freshwater green algae include a greater diversity of cellular organization, morphological structures and reproductive processes than any other algae (Bold et al. 1978). The order Chlorococcales occur in the plankton and benthos of mesotrophic or eutrophic and waters and the highest frequency and abundance. Especially from spring to fall, their reproduction is so extensive that they can bring about a strong green coloration of the water (Hindak 1977). Thus, they play an important role in primary and secondary successional processes (John and Tsarenko 2002).

Studies in freshwater algae in Korea were initiated by Kawamura (1918), who first reported the genus Cenritractus in Lake Suwon Seoho. Since then, 58 taxa have been reported, included 1 new species and 1 new variety from Lake Suwon Seoho by Skvortzow (1929). Ueno (1940) investigated and reported the taxa in Lake Bujeon, swamp Daetaek, the Aprok river, the upper reach of Namdaecheon stream and Jooeul hot springs. The earlier studies on the taxonomy of freshwater algae in Korea were carried out by foreign scholars (Kawamura 1918, Skvortzow 1929, Ueno 1940). Korean florists later reported further Korean freshwater algal species from reservoirs, dam lakes, hot springs and other areas. (Chung 1974, 1978, 1981, Chung and Kim 1991, 1992, Chung et al. 1972, Kim et al. 1991, 1994). These studies were mostly focused on the Youngnam area.

Families Botryococcaceae and Dictyosphaeriaceae are divided or merged according to a few scholars. Prescott (1962) included the family Dictyosphaeriaceae in the family Oocystaceae, which is composed of unicellular species or colonies. However, Smith (1950) separately classified the family Dictyosphaeriaceae, as cells in the genus Dictyosphaerium, Dimorphococcus and Botryococcus arranged the end of branched mucilaginous threads from mother cell walls, whereas family Oocystaceae did not. Komarek and Fott (1983) merged the family Dictyosphaeriaceae into the family Botryococcaceae. The family Botryococcaceae are cosmopolitan and widely distrib- http://dx.doi.org/10.5141/ecoenv.2013.327

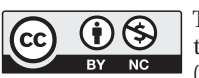

This is an Open Access article distributed under the terms of the Creative Commons Attribution Non-Commercial Licens (http://creativecommons.org/licenses/by-nc/3.0/) which permits unrestricted non-commercial use, distribution, and reproduction in any medium, provided the original work is properly cited.
Received 29 October 2013, Accepted 12 November 2013

*Corresponding Author

E-mail: yjkim@daejin.ac.kr

Tel: +82-31-539-1851 
uted in many types of aquatic habitats, including ditches, bog pools, ponds, reservoirs and lakes. Sometimes it is appearing as masses of suspended green and brown coloration. Size of cells and colonies depend largely on environmental conditions (Komarek and Fott 1983, John and Tsarenko 2002).

Genera belonging to the family Characiaceae are solitary or are joined in radiate colonies, and may be attached on other filamentous algae or free floating. This family is very small, and includes the genus Characium, Ankyra, Schroederia and Actidesmium etc.

The reported taxa belong to the family Botryococcaceae and Characiaceae in Korea comprise a total of 6 genera and 13 species, which are Dictyosphaerium ehrenbergianum, D. pulchellum, Dichotomococcus curvatus, Botryococcus braunii, Characium ambiguum, C. acuminatum, C. limneticum, C. obtusum, C. pringsheimii, C. rostratum, Schroederia setigera, Ankyra paradoxioides and Korshikoviella michailovskoensis.

The purpose of this study is to reviewed about newly recorded species in algal flora of Korea (Kim and Kim 2012) of the family Botryococcaceae and Characiaceae, Chlorococcales and Chlorophyceae, representing 8 genera and 20 species collected from swamps, ponds, reservoirs, lakes and rivers in Korea from May 2011 to January 2012 (Table 1). We present taxonomic information, illustrations, classifications, references, synonyms, basionyms and distributions in Korea.

\section{MATERIALS AND METHODS}

The samples of Chlorococcal algae were collected at 21 stations including ponds, swamp, reservoirs, lakes and rivers from May 2011 to January 2012 (Table 1). Sampling stations were located throughout the country. All samples were collected using $10 \mu \mathrm{m}$ or $20 \mu \mathrm{m}$ mesh-sized plankton nets with vertical and/or horizontal towing, or submerged benthic or soil algae with spoid or brush. Chlorococcal algae samples were immediately fixed with Lugol's iodine solution $(0.5 \%)$ for immobilizing the cells to facilitate microscopic examination. To examine the fine structures and cellular shapes, and to identify and classify the Chlorococcal species, a temporary slide was made using the follow steps: 1) the phytoplankton samples (Chloroccocal algae) were mixed with glycerin in micro tubes. 2) The mixed samples were placed, drop-wise on slide glass, and were fixed in position with cover slides. Permanent slides were made using the follow steps: 1) the phytoplankton samples (Chloroccocal algae) were mixed with liquid glycerol gelatin for mounting histochemical slides (Sigma-Aldrich, St. Louis, MO, USA). 2) The mixed sample was placed drop-wise on slide glass and was fixed in position with a cover slide. 3) It was cemented the margin of a cover glass with manicure (Thecashop, Seoul, Korea). The temporary and permanent slides were observed at $\times$ 200 to $\times 1,000$ magnification using light microscopy (LM) ( Axioskop 20 and Axio Imager A2; Carl Zeiss) with an attached digital camera ( Axiocam HRc; Carl Zeiss ) being used to capture images. The scale bar in illustrations represents $10 \mu \mathrm{m}$.

At each station, physical and chemical factors of water were recorded during the sampling periods. Water temp. (Water temperature, ${ }^{\circ} \mathrm{C}$ ) and EC (electric conductivity) was measured in situ using a portable thermometer and EC meter (Orion 5-star; Thermo Scientific, Waltham, MA, USA) and a $\mathrm{pH}$ was measured in situ using a $\mathrm{pH}$ meter (Ultrabasic-5; Denver Instrument, Bohemia, NY, USA) respectively. This study used the data of total nitrogen (TN) and total phosphate (TP) concentrations at each sampling station from the water information system of the Ministry of Environment (NIER 2013).

Chlorococcal algae identification were mainly based on Komarek and Fott (1983), John and Tsarenko (2002), Hindak (1977, 1980, 1984, 1988), Prescott (1962), Hirose and Yamagishi (1977) and Yamagishi and Akiyama (19841996).

\section{RESULTS AND DISCUSSION}

Family Botryococcaceae and Characiaceae, of the order Chlorococcales are composed of 8 genera, 20 species in this study. 10 taxa of these families are newly recorded in algal flora of Korea and reviewed in this study : Dictyosphaerium elegans, D. reniforme, D. simplex, D. elongatum, Characium conicum, Ankyra ancora, A. judayi, A. calcarifera, Schroederia spiralis, S. indica. This study described the taxonomic information, illustration, classification, reference, basionym, synonym and distribution of the new recorded species of these families.

\section{Division Chlorophyta \\ Class Chlorophyceae \\ Order Chlorococcales \\ Family Botryococcaceae}

\section{Genus Dictyosphaerium G.S. West}

Dictyosphaerium pulchellum Wood 1873 
Cells spherical, 3-10 $\mu \mathrm{m}$ in diameter.

\section{Dictyosphaerium elegans Nägeli 1849 (Fig. 1)}

Synonym: Pseudodictyosphaerium elegans (Bachman) Hindak 1988.

Illustration: Colonies free-floating, and composed of 16,32 cells, enclosed with a hyaline, gelatinous envelope. Cells ovoid to ellipsoid or reverse egg-form having one end slightly narrow than the other, attached with the narrow end to radially, di- or tetrachotomously branched gelatinous threads, lying sparsely near periphery of the gelatinous envelope, grouping generally in four cells which are distant from one another. A single chloroplast is cupshaped, without a pyrenoid. Cells 2-7 $\mu \mathrm{m}$ in diameter, and 3-8 $\mu \mathrm{m}$ long.

Information of sampling sites: This species inhabits lakes and reservoirs as plankton, and was collected from Lake Seoho (03 Sep 2011: water temp. $24.1^{\circ} \mathrm{C}$, pH 7.3; EC $569 \mathrm{\mu s} \mathrm{cm}^{-1}$, TN $6.515 \mathrm{mg} \mathrm{L}^{-1}$, TP $0.278 \mathrm{mg} \mathrm{L}^{-1}$ ), Ugeum reservoir (29 Aug 2011: water temp. $25.9^{\circ} \mathrm{C}$, pH 7.5, EC $128 \mu \mathrm{s}$ $\mathrm{cm}^{-1}$, TN $1.675 \mathrm{mg} \mathrm{L}^{-1}$, TP $0.043 \mathrm{mg} \mathrm{L}^{-1}$ ).

Key reference: Bachmann (1913).

Remark: This taxon is already reported in Algal flora of Korea by Kim and Kim (2012).

Table 1. Sampling sites of Botryococcaceae and Characiaceae, Chlorococcales, 2011 and 2012.

\begin{tabular}{|c|c|c|c|}
\hline Station & Collected data & Locality & Coordinate \\
\hline Estuary Dam of Gumgang river & 05 May 2011, 07 Oct. 2011 & Seongduk, Gunsan, Jellabuk-do & $\begin{array}{l}36^{\circ} 00^{\prime} 59^{\prime \prime} \mathrm{N}, \\
126^{\circ} 44^{\prime} 55^{\prime \prime} \mathrm{E}\end{array}$ \\
\hline Nakdong river & 10 Aug 2011, 25 Oct 2011 & $\begin{array}{l}\text { Gilgok, Changnyeong, } \\
\text { Gyeongsangnam-do }\end{array}$ & $\begin{array}{l}35^{\circ} 23^{\prime} 26^{\prime \prime} \mathrm{N}, \\
128^{\circ} 35^{\prime} 51^{\prime \prime} \mathrm{E}\end{array}$ \\
\hline Pond of Daejin university & 29 Aug 2011 & Seondan, Pocheon, Gyeonggi-do & $\begin{array}{l}37^{\circ} 52^{\prime} 29^{\prime \prime} \mathrm{N}, \\
127^{\circ} 09^{\prime} 28^{\prime \prime} \mathrm{E}\end{array}$ \\
\hline Donghwa stream & 24 Sep 2011 & Bibong, Hwaseong, Gyeonggi-do & $\begin{array}{l}37^{\circ} 15^{\prime} 23^{\prime \prime} \mathrm{N}, \\
126^{\circ} 53^{\prime} 07^{\prime \prime} \mathrm{E}\end{array}$ \\
\hline Samrak park & 03 Nov 2011 & Samrak, Sasang, Busan & $\begin{array}{l}35^{\circ} 10^{\prime} 09^{\prime \prime} \mathrm{N}, \\
128^{\circ} 58^{\prime} 06^{\prime \prime} \mathrm{E}\end{array}$ \\
\hline Lake Baekwoon & 02 Sep 2011 & Cheonggi, Uiwang, Gyeonggi-do & $\begin{array}{l}37^{\circ} 22^{\prime} 33^{\prime \prime} \mathrm{N} \\
127^{\circ} 00^{\prime} 17^{\prime \prime} \mathrm{E}\end{array}$ \\
\hline Lake Pomun & 10 Sep 2011, 21 Jan 2012 & Boduk, Gyeongju, Gyeongsangbuk-do & $\begin{array}{l}35^{\circ} 50^{\prime} 20^{\prime \prime} \mathrm{N}, \\
129^{\circ} 16^{\prime} 45^{\prime \prime} \mathrm{E}\end{array}$ \\
\hline Lake Bongpo & 15 Aug 2011 & Toseong, Goseong, Gangwon-do & $\begin{array}{l}38^{\circ} 14^{\prime} 27^{\prime \prime} \mathrm{N}, \\
128^{\circ} 34^{\prime} 08^{\prime \prime} \mathrm{E}\end{array}$ \\
\hline Bukhan river & 17 Dec 2011 & Hwado, Namyangju, Gyeonggi-do & $\begin{array}{l}37^{\circ} 40^{\prime} 20^{\prime \prime} \mathrm{N}, \\
127^{\circ} 34^{\prime} 00^{\prime \prime} \mathrm{E}\end{array}$ \\
\hline Lake Seoho & 03 Sep 2011, 20 Nov 2011 & Hwaseo 2, Suwon, Gyeonggi-do & $\begin{array}{l}37^{\circ} 16^{\prime} 40^{\prime \prime} \mathrm{N}, \\
126^{\circ} 59^{\prime} 15^{\prime \prime} \mathrm{E}\end{array}$ \\
\hline Lake 88 & 01 Sep 2011 & Olympic park, Bang-i,Songpa, Seoul & $\begin{array}{l}37^{\circ} 31^{\prime} 14^{\prime \prime} \mathrm{N}, \\
127^{\circ} 07^{\prime} 03^{\prime \prime} \mathrm{E}\end{array}$ \\
\hline Wangsong reservoir & 03 Sep 2011 & Bugok, Uiwang, Gyeonggi-do & $\begin{array}{l}37^{\circ} 18^{\prime} 05^{\prime \prime} \mathrm{N} \\
127^{\circ} 56^{\prime} 09^{\prime \prime} \mathrm{E}\end{array}$ \\
\hline Fishery of Ugeum & $\begin{array}{l}29 \text { May 2011, } 29 \text { Aug 2011, } \\
31 \text { Oct } 2011\end{array}$ & Gasan, Pocheon, Gyeonggi-do & $\begin{array}{l}37^{\circ} 49^{\prime} 33^{\prime \prime} \mathrm{N} \\
127^{\circ} 12^{\prime} 39^{\prime \prime} \mathrm{E}\end{array}$ \\
\hline Ugeum reservoir & $\begin{array}{l}29 \text { May 2011, } 29 \text { Aug 2011, } \\
31 \text { Oct } 2011\end{array}$ & Gasan, Pocheon, Gyeonggi-do & $\begin{array}{l}37^{\circ} 49^{\prime} 40^{\prime \prime} \mathrm{N}, \\
127^{\circ} 12^{\prime} 41^{\prime \prime} \mathrm{E}\end{array}$ \\
\hline Ilgam reservoir & 19 Dec 2011 & Jayang, Gwangjin, Seoul & $\begin{array}{l}37^{\circ} 32^{\prime} 26^{\prime \prime} \mathrm{N}, \\
127^{\circ} 04^{\prime} 35^{\prime \prime} \mathrm{E}\end{array}$ \\
\hline Ilwang reservoir & 03 Sep 2011 & Songcheok, Suwon, Gyeonggi-do & $\begin{array}{l}37^{\circ} 17^{\prime} 59^{\prime \prime} \mathrm{N}, \\
127^{\circ} 00^{\prime} 02^{\prime \prime} \mathrm{E}\end{array}$ \\
\hline Ilweol reservoir & 29 Aug 2011 & Jincheon, Suwon, Gyeonggi-do & $\begin{array}{l}37^{\circ} 17^{\prime} 09^{\prime \prime} \mathrm{N} \\
126^{\circ} 58^{\prime} 26^{\prime \prime} \mathrm{E}\end{array}$ \\
\hline Jangcheok swamp & 15 Aug 2011 & $\begin{array}{l}\text { Shinje, Youngsan, Changnyeong, } \\
\text { Gyeongsangnam-do }\end{array}$ & $\begin{array}{l}35^{\circ} 26^{\prime} 01^{\prime \prime} \mathrm{N} \\
128^{\circ} 29^{\prime} 54^{\prime \prime} \mathrm{E}\end{array}$ \\
\hline Pond of Jungang park & 30 Oct 2011 & $\begin{array}{l}\text { Sunae, Bundang, Seongnam, } \\
\text { Gyeonggi-do }\end{array}$ & $\begin{array}{l}37^{\circ} 22^{\prime} 30^{\prime \prime} \mathrm{N}, \\
127^{\circ} 07^{\prime} 32^{\prime \prime} \mathrm{E}\end{array}$ \\
\hline Pond of KAIST & 28 Aug 2011, 18 Dec 2011 & Guseong, Yuseong, Daejeon & $\begin{array}{l}36^{\circ} 22^{\prime} 05^{\prime \prime} \mathrm{N} \\
127^{\circ} 21^{\prime} 44^{\prime \prime} \mathrm{E}\end{array}$ \\
\hline Lake Paldang & 22 Aug 2011 & Joan, Namyangju, Gyeonggi-do & $\begin{array}{l}37^{\circ} 30^{\prime} 53^{\prime \prime} \mathrm{N}, \\
127^{\circ} 18^{\prime} 03^{\prime \prime} \mathrm{E}\end{array}$ \\
\hline
\end{tabular}



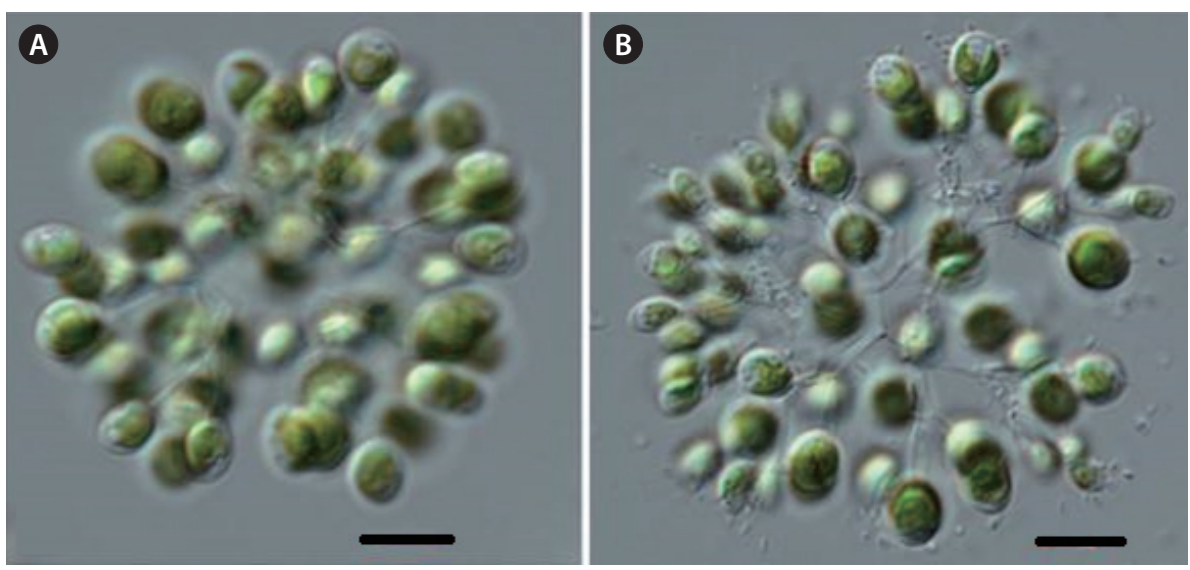

Fig. 1. Dictyosphaerium elegans Nägeli (A- B: each other individual). Scale bars, $10 \mu \mathrm{m}$.

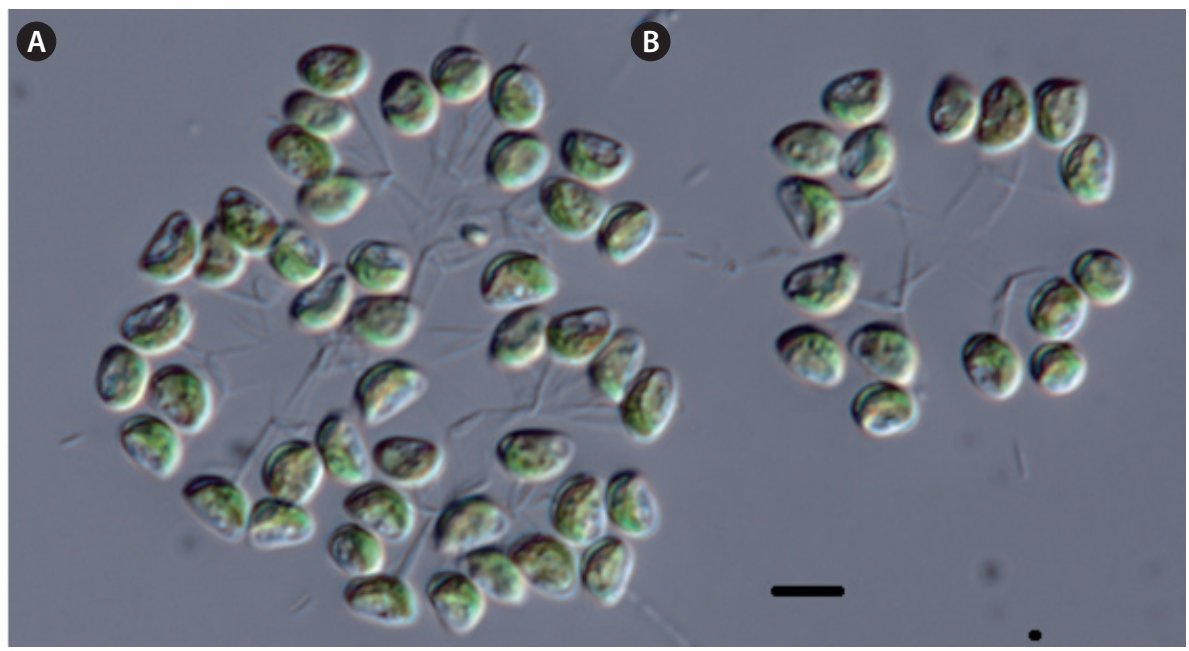

Fig. 2. Dictyosphaerium reniforme Bulnheim (A-B: each other individual). Scale bars, $10 \mu \mathrm{m}$.
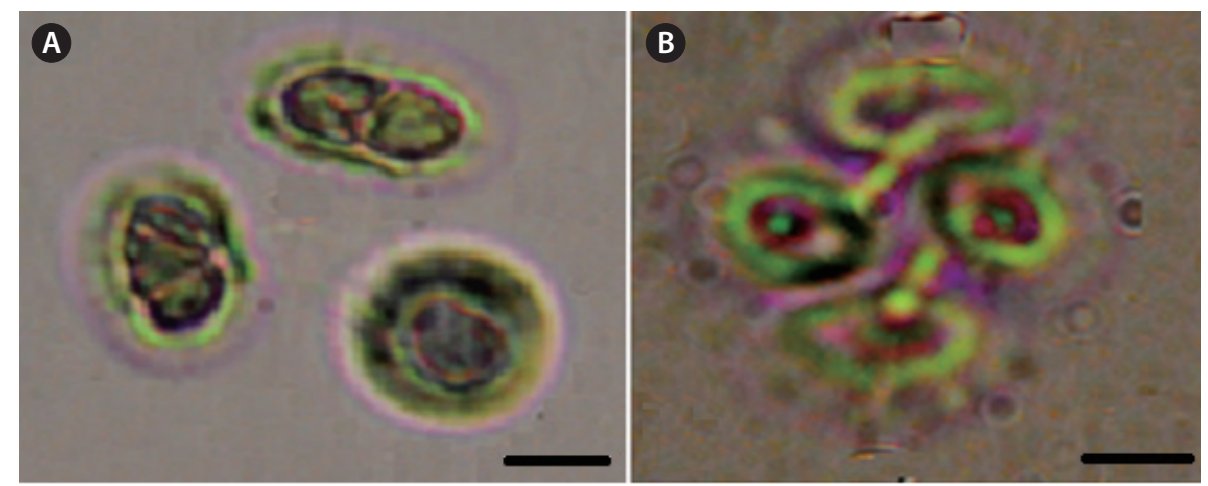

Fig. 3. Dictyosphaerium simplex Korshikov (A-B: each other individual). Scale bars, $10 \mu \mathrm{m}$. 

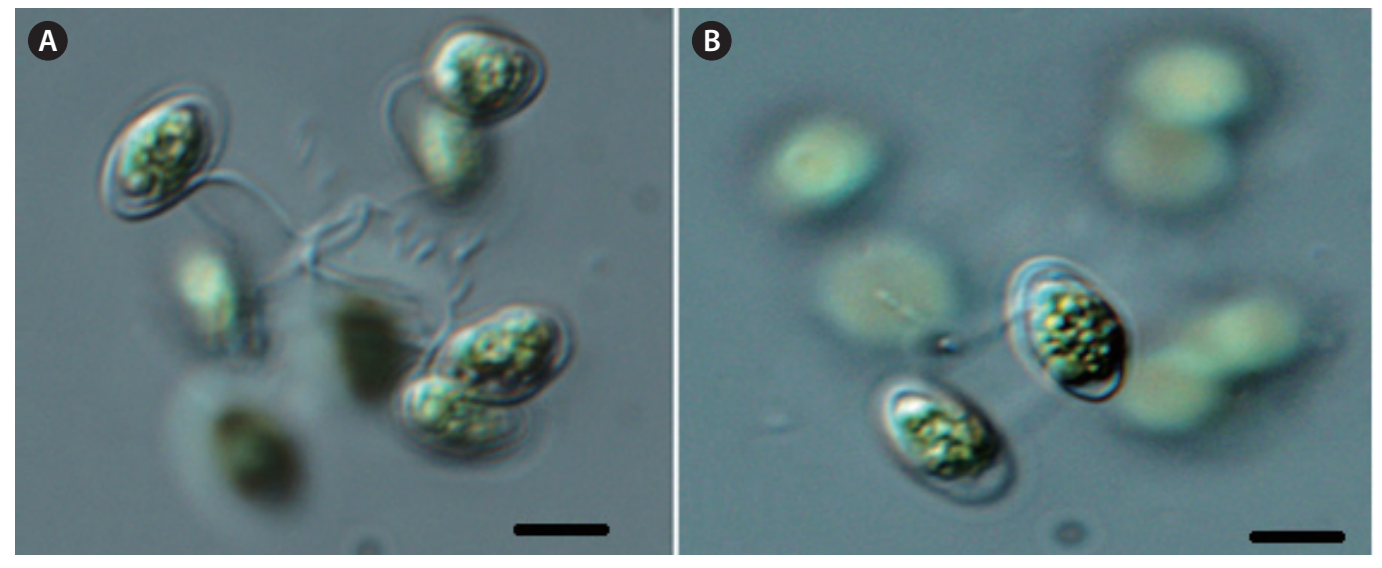

Fig. 4. Dictyosphaerium elongatum Hindak (A-B: each other individual). Scale bars, $10 \mu \mathrm{m}$.

\section{Dictyosphaerium ehrenbergianum Nägeli}

Cells are oval, ellipsoidal. Cells 3-7 $\mu \mathrm{m}$ in diameter, and 4-10um long.

\section{Dictyosphaerium reniforme Bulnheim 1859 (Fig. 2)}

Illustration: Colonies free-floating, spherical to broad ellipsoid, and composed of 16-64 or more cells, enclosed with a hyaline, gelatinous envelope. Cells reniform in side view and broad-ellipsoid in face view attached by their convex side to the radially, di- or tetrachotomously branched gelatinous threads, lying near the periphery of the gelatinous envelope, grouping generally in four cells. Single chloroplast, cup-shaped, lying on the convex side of the cells, with a pyrenoid. Cells 3-10 $\mu \mathrm{m}$ in diameter, and 6-20 $\mu \mathrm{m}$ long.

Information of collected sites: This species inhabits lakes and reservoirs as plankton, and was collected from Lake Soeho (03 Sep 2011: water temp. $24.1^{\circ} \mathrm{C}$, pH 7.3, EC $569 \mu \mathrm{sm}^{-1}$, TN $6.515 \mathrm{mg} \mathrm{L}^{-1}$, TP $0.278 \mathrm{mg} \mathrm{L}^{-1}$ ).

Key reference: Bulnheim (1859).

Remark: This taxon is already reported in Algal flora of Korea by Kim and Kim (2012).

\section{Dictyosphaerium simplex Korshikov 1953 (Fig. 3)}

Synonym: Dictyosphaerium chlorelloides (Nauman) Komarek et Perman 1978; Dictyosphaerium pulchellum var. ovatum Korshikov 1953; Dictyosphaerium tetrachotomum Printz sensu Hindak 1984;

Dictyosphaerium chlorelloides (Naumann) Komarek et Perman 1978; Dictyopshaerium tetrachotomum var. minutum (Taylor) Komarek 1983.

Illustration: Colonies free floating, composed of 4-64 celled, only rarely containing more cells, with distinct and regular stalk branching, 4-celled colonies 25-40 $\mu \mathrm{m}$ in diameter, 64 celled to $50 \mu \mathrm{m}$ in diameter. Mucilaginous envelopes hyaline, not stratified, 5-8 $\mu \mathrm{m}$ round cells. Cell shape varies depending on age. Mature cells spherically oval or oval, attached to stalks laterally, by the medium part of the longer wall on di- or tetrachotomously branched gelatinous threads, lying near the periphery of the gelatinous envelope, grouping generally in four cells. Sporadically a continuous layer of dense mucilage to 2 $\mu \mathrm{m}$ thick is formed around cells, or a fine layer of regularly distributed short rod-like colorless spines. Chloroplast cup-shaped, with one big oval pyrenoid. Cells 8-15 $\mu \mathrm{m}$ in diameter, and 13-20 $\mu \mathrm{m}$ long.

Information of sampling sites: This species inhabits lakes and reservoirs as plankton, and is collected from Lake Seoho (03 Sep 2011: water temp. $24.1^{\circ} \mathrm{C}$, pH 7.3, EC $569 \mu \mathrm{cm}^{-1}$, TN $6.515 \mathrm{mg} \mathrm{L}^{-1}$, TP $0.278 \mathrm{mg} \mathrm{L}^{-1}$ ), Ugeum reservoir (29 Aug 2011: water temp. $25.9^{\circ} \mathrm{C}, \mathrm{pH} 7.5$, EC $128 \mu \mathrm{s}$ $\mathrm{cm}^{-1}$, TN $1.675 \mathrm{mg} \mathrm{L}^{-1}$, TP $\left.0.043 \mathrm{mg} \mathrm{L}^{-1}\right)$.

Key reference: Korsikov (1953).

Remark: This taxon is already reported in Algal flora of Korea by Kim and Kim (2012).

\section{Dictyosphaerium elongatum Hindak 1977 (Fig. 4)}

Synonym: Steiniella gravenitzii Bernard sensu Skuja.

Illustration: Colonies free-floating, spherical to ellipsoid, composed of $4,16,32$, or 64 celled or more celled with distinct and regular gelatinous threads branching, gelatinous envelopes hyaline, not stratified. Cells long, asymmetrically oval-fusiform, attached to the branched gelatinous threads by the median portion of cells. Single 
chloroplast, cup-shaped included a pyrenoid. Cells 6-10 $\mu \mathrm{m}$ in diameter, and 15-20 $\mu \mathrm{m}$ long.

Information of sampling sites: This species inhabit in lakes and reservoirs as plankton, and was collected from Lake Soeho (03 Sep 2011: water temp. $24.1^{\circ} \mathrm{C}$, pH 7.3, EC $569 \mu \mathrm{cm}^{-1}$, TN $6.515 \mathrm{mg} \mathrm{L}^{-1}$, TP $0.278 \mathrm{mg} \mathrm{L}^{-1}$ ), Ugeum reservoir (29 Aug 2011: water temp. $25.9^{\circ} \mathrm{C}$, pH 7.5, EC $128 \mu \mathrm{s}$ $\mathrm{cm}^{-1}$, TN $1.675 \mathrm{mg} \mathrm{L}^{-1}$, TP $0.043 \mathrm{mg} \mathrm{L}^{-1}$ ).

Key reference: Hindak (1977).

Remark: This taxon is already reported in Algal flora of Korea by Kim and Kim (2012).

\section{Genus Dimorphococcus A. Braun}

\section{Dimorphococcus lunatus A. Braun}

Cells reniform to cordate with rounded ends. Cells 4-15 $\mu \mathrm{m}$ in diameter, and 9-25 $\mu \mathrm{m}$ long

\section{Genus Dichotomococcus Korshikov}

\section{Dichotomococcus curvatus Korshikov 1939}

Cells elongate-ovoid to ellipsoid, broader at the base than at the poles, in radially arranged in groups of 2-4 apposed at their bases, cell groups at the periphery of wide, homogeneous mucilage envelope. Cells $2-4 \mu \mathrm{m}$ in diameter, and 5.5-11 $\mu \mathrm{m}$ long.

\section{Genus Botryococcus Kützing 1849}

\section{Botryococcus braunii Kützing 1849}

Colonies globes or ovoid, botryoidal, cells elongated, ovoid or ellipsoid. Cells 3-6 $\mu \mathrm{m}$ in diameter, and 6-15 $\mu \mathrm{m}$ long.

\section{Family Characiaceae (Nägeli) Wille in Warming 1884}

\section{Genus Characium A. Braun in Kützing 1849}

\section{Characium rostratum Rabenhorst ex Printz 1914}

Cells elongated fusiform, slightly curved. Cells with stipe 5-8 $\mu \mathrm{m}$ in diameter, and 28-36 $\mu \mathrm{m}$ long.

\section{Characium pringsheimii (A. Braun) Komarek 1855}

Cells narrowly elongated ovoid to fusiform. Cells with stipe $7-10 \mu \mathrm{m}$ in diameter, and 18-33 $\mu \mathrm{m}$ long.

\section{Characium ambiguum Hermann in Rabenhorst 1863}

Cells lanceolate, fusiform or ensiform shaped. Cells with stipe 4-8 $\mu \mathrm{m}$ in diameter, and 25-32 $\mu \mathrm{m}$ long.
Characium conicum Korshikov 1953 in Komarek et Fott 1983 (Fig.5)

Synonym: Characium bulbosum Korshikov; Characium naegeli A. Braun sensu Skuja.

Illustration: Cells narrowly wide-ovoid to fusiform, erect but with a short oblique tip, stipe short, chloroplast a parietal, with a pyrenoid. Cells 10-15 $\mu \mathrm{m}$ in diameter, and 15-30 $\mu \mathrm{m}$ long.

Information of sampling sites: This species attached on filamentous green algae or plants, and were collected from Samrak park (03 Oct 2011: Water temp. $20.0^{\circ} \mathrm{C}$, TN $2.030 \mathrm{mg} \mathrm{L}^{-1}$, TP $\left.0.112 \mathrm{mg} \mathrm{L}^{-1}\right)$.

Key reference: Komarek and Fott (1983).

Remark: This taxon is already reported in Algal flora of Korea by Kim and Kim (2012) and was collected by Han Soon Kim.

\section{Genus Ankyra (G.M. Smith) Fott}

\section{Ankyra ancora (G.M. Smith) Fott 1975 (Fig. 6A, 6B)}

Basionym: Schroederia setigera var. ancora G.M. Smith . Synonym: Schroederia ancora G.M. Smith; Characium ancora (G.M. Smith) Fott.

Illustration: Cells solitary, spindle-like, fusiform, commonly straight, but sometimes slightly covered. The anterior pole tapers to a long bristle bearing either a pair of leaf-like appendages or a cluster of horse tail-like bristles. The posterior pole tapers gradually and bifurcates the processes as an anchor-like shape. Chloroplasts single, with a pyrenoid. Cells (included stipe) 5-16 $\mu \mathrm{m}$ in diameter, and 130-150 $\mu \mathrm{m}$ long.

Information of sampling sites: This species inhabits lakes and reservoirs as plankton, and is collected from the Nakdong river (25 Oct 2011: water temp. $20.0^{\circ} \mathrm{C}, \mathrm{pH}$ 8.0, TN $2.044 \mathrm{mg} \mathrm{L}^{-1}$, TP $0.073 \mathrm{mg} \mathrm{L}^{-1}$ ), Samrak Park (03 Oct 2011: water temp. $20.0^{\circ} \mathrm{C}$, pH 8.0, TN $2.030 \mathrm{mg} \mathrm{L}^{-1}$, TP 0.112 $\mathrm{mg} \mathrm{L}^{-1}$ )

Key reference: Fott (1957).

Remark: This taxon is already reported in Algal flora of Korea by Kim and Kim (2012) and was collected by Han Soon Kim.

\section{Ankyra judayi (G.M. Smith) Fott (Fig. 6C)}

Basionym: Schroederia judayi G.M. Smith.

Synonym: Lambertia judayi (G.M. Smith) Ergashev; Schroederia judayi G.M. Smith; Korshikoviella judayi (G.M. Smith) Ergashev.

Illustration: Cells solitary, spindle-like, fusiform, commonly straight, but sometimes slightly covered. The anterior pole tapers to a long bristle which bears either a 

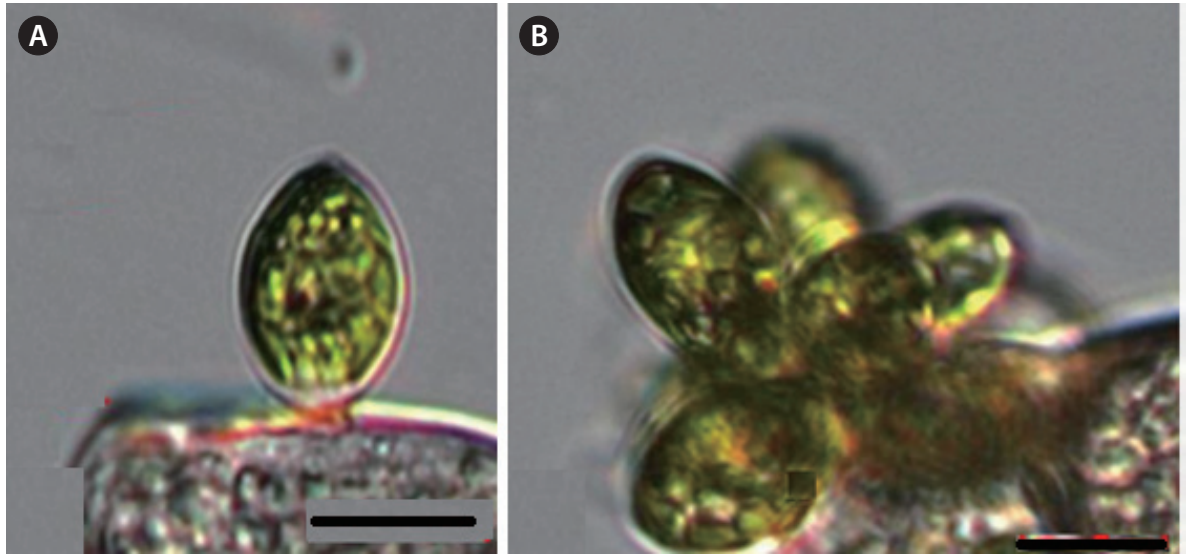

Fig. 5. Characium conicum Korshikov (A-B: each other individual). Scale bars, $10 \mu \mathrm{m}$.
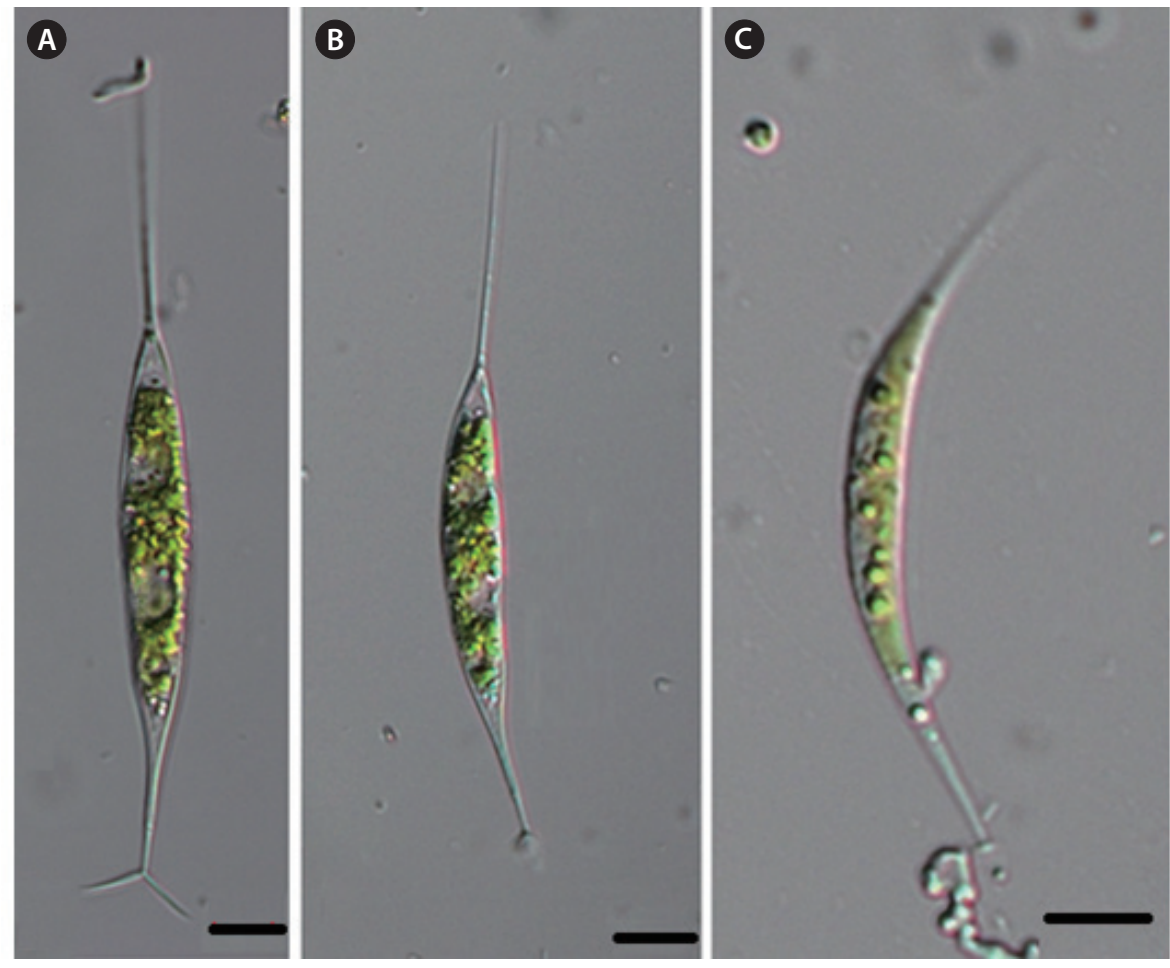

Fig. 6. (A-B) Ankyra ancora (G.M. Smith) Fott, (C) Ankyra judayi (G.M. Smith) Fott. Scale bars, $10 \mu \mathrm{m}$.

pair of leaf-like appendages or a cluster of horse tail-like bristles. The posterior pole tapers gradually and bifurcates the processes as an anchor-like shape. Chloroplasts a parietal plates, with a pyrenoid. Cells (included stip) 6 $\mu \mathrm{m}$ in diameter, and 18-80 $\mu \mathrm{m}$ long.

Information of sampling sites: This species inhabits lakes and reservoirs as plankton and, collected from the Nakdong river (25 Oct 2011: water temp. $20.0^{\circ} \mathrm{C}, \mathrm{pH}$ 8.0,
TN $2.044 \mathrm{mg} \mathrm{L}^{-1}$, TP $0.073 \mathrm{mg} \mathrm{L}^{-1}$ ), Samrak park (03 Oct 2011: water temp. $20.0^{\circ} \mathrm{C}$, pH 8.0, TN $2.030 \mathrm{mg} \mathrm{L}^{-1}$, TP 0.112 $\mathrm{mg} \mathrm{L} \mathrm{L}^{-1}$.

Key reference: Fott (1957).

Remark: This taxon is already reported in Algal flora of Korea by Kim and Kim (2012) and was collected by Han Soon Kim. 


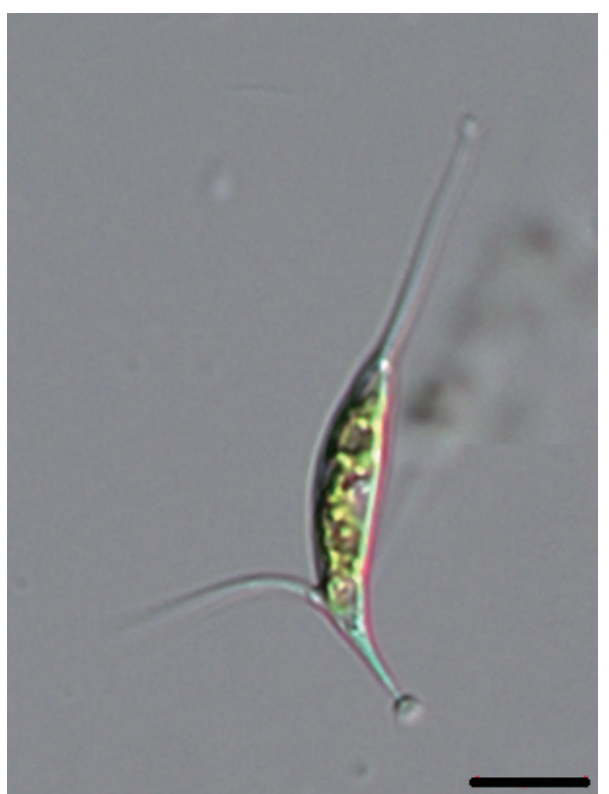

Fig. 7. Ankyra calcarifera (Kisselev) Fott. Scale bar, $10 \mu \mathrm{m}$.

\section{Ankyra calcarifera (Kisselev) Fott (Fig. 7) \\ Basionym: Lambertia calcarifera Kisselev 1955.}

Illustration: Cells solitary, spindle-like, fusiform, commonly straight, but sometimes slightly covered. The anterior pole tapers, to a long bristle bearing either a pair of leaf-like appendages or a cluster of horse tail-like bristles. The posterior pole tapers gradually and bifurcates the processes as anchor-like shape, a crooked bristle is on the convex side of the cell. Chloroplast a parietal, with a pyrenoid. Cells 5-7 $\mu \mathrm{m}$ in diameter, 40-50 $\mu \mathrm{m}$ long, and bristle on the convex side wall $30 \mu \mathrm{m}$ long.

Information of sampling sites This species inhabit lakes and reservoirs as plankton, and was collected from the Nakdong river (25 Oct 2011: water temp. $20.0^{\circ} \mathrm{C}, \mathrm{pH}$ 8.0, TN $2.044 \mathrm{mg} \mathrm{L}^{-1}$, TP $0.073 \mathrm{mg} \mathrm{L}^{-1}$ ), Samrak park (03 Oct 2011: Water temp. $20.0^{\circ} \mathrm{C}$, pH 8.0, TN $2.030 \mathrm{mg} \mathrm{L}^{-1}$, TP $0.112 \mathrm{mg} \mathrm{L}^{-1}$ ).

Key reference: Fott (1957).

Remark: This taxon is already reported in Algal flora of Korea by Kim and Kim (2012) Han Soon Kim.

\section{Genus Paradoxa Svirenko 1928}

\section{Paradoxa multiseta Svirenko 1928 (Fig. 8)}

Illustration: Cells fusiform, the anterior pole tapering gradually to a long bristle, bearing either a pair of leaf-like appendages or a number of bristles, 18-45 $\mu \mathrm{m}$ long and 3-8 $\mu \mathrm{m}$ wide, The leaf-like appendages are 1-6 $\mu \mathrm{m}$ long and up to $2.3 \mu \mathrm{m}$ in diameter at their base, and give the cell an anchor-like shape.

Information of sampling sites: This species inhabits lakes and reservoirs as plankton, and was collected from the Nakdong river (25 Oct 2011: water temp. $20.0^{\circ} \mathrm{C}, \mathrm{pH}$ 8.0, TN $2.044 \mathrm{mg} \mathrm{L}^{-1}$, TP $\left.0.073 \mathrm{mg} \mathrm{L}^{-1}\right)$.

Key reference: Svirenko (1928).

Remark : This was collected by Han Soon Kim (2011) from the Nakdong river. This genus Paradoxia was planktonic and rare in lakes and pools. Structure of anterior appendages and other features of this genus are similar to those of Ankyra. If Paradoxia species do not form a coenobium with an anchor-like appendage at the posterior base of two cells, they may be easily confused with Ankyra. Species distinguished based on the protoplast shape, the presence/absence of a coenobium, and leaf-like appendages. This taxon is already reported in Algal flora of Korea by Kim and Kim (2012).

\section{Genus Schroederia Lemmermann}

\section{Schroederia setigera (Schröder) Lemmermann}

Cells spindle form, fusiform and crescent form. Cells with setae 4-6 $\mu \mathrm{m}$ in diameter, and 25-60 $\mu \mathrm{m}$ long.

\section{Schroederia spiralis (Printz) Korshikov 1953 (Fig. 9)}

Basionym: Ankistrodesmus nitzschioides var. spiralis Printz.

Illustration: Cells solitary, spindle-form, fusiform, crescent form. The poles extend into long, fine setae, spirally twisted with setae, without a small disk. Chloroplast a single, parietal, laminate, with a pyrenoid. Cells (with setae) 25-60 $\mu \mathrm{m}$ long, and 4-6 $\mu \mathrm{m}$ in diameter.

Information of collected sites: This species inhabits lakes and reservoirs as plankton, and was collected from Lake Seoho (20 Nov 2011: water temp. 8.1 ${ }^{\circ} \mathrm{C}$, pH 7.9, TN $2.730 \mathrm{mg} \mathrm{L}^{-1}$, TP $0.055 \mathrm{mg} \mathrm{L}^{-1}$ ), Donghwa stream (23 Sep 2011: water temp. $22.9^{\circ} \mathrm{C}$, pH 7.6, TN $7.277 \mathrm{mg} \mathrm{L}^{-1}$, TP 0.050 $\mathrm{mg} \mathrm{L}^{-1}$ ), Nammae reservoir (10 Sep 2011: water temp. 28.0 $0^{\circ} \mathrm{C}$, pH 8.4, TN $2.916 \mathrm{mg} \mathrm{L}^{-1}$, TP $0.083 \mathrm{mg} \mathrm{L}^{-1}$ ), Ilweul reservoir (03 Sep 2011: water temp. $30.0^{\circ} \mathrm{C}$, pH 8.2, EC 636 $\mu \mathrm{cm}^{-1}$ ), Pond at Samrak park (03 Oct 2011: water temp. 20.0 ${ }^{\circ} \mathrm{C}, \mathrm{pH}$ 8.0, TN $2.030 \mathrm{mg} \mathrm{L}^{-1}$, TP $0.112 \mathrm{mg} \mathrm{L}^{-1}$ ).

Key reference: Korshikov (1939).

\section{Schroederia indica Philipose 1967 (Fig. 10)}

Illustration: Cells solitary, spindle-form, fusiform, crescent form. cells curved, convex on the outer side and slightly convex or swollen on the inner side. Both poles extended into long, fine setae, setae straight, point. Chloroplast a parietal, with a pyrenoid. Cells (include setae) 

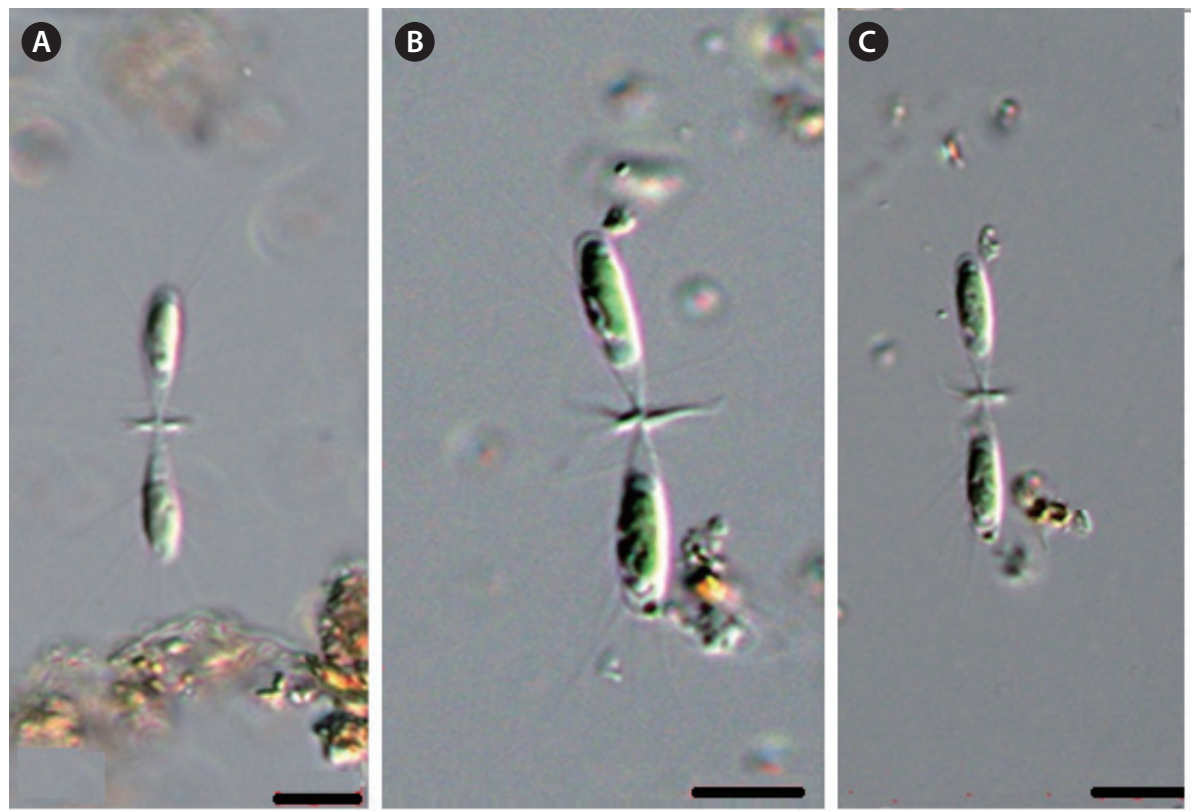

Fig. 8. Paradoxa multiseta Svirenko (A-C: each other individual). Scale bars, $10 \mu \mathrm{m}$.

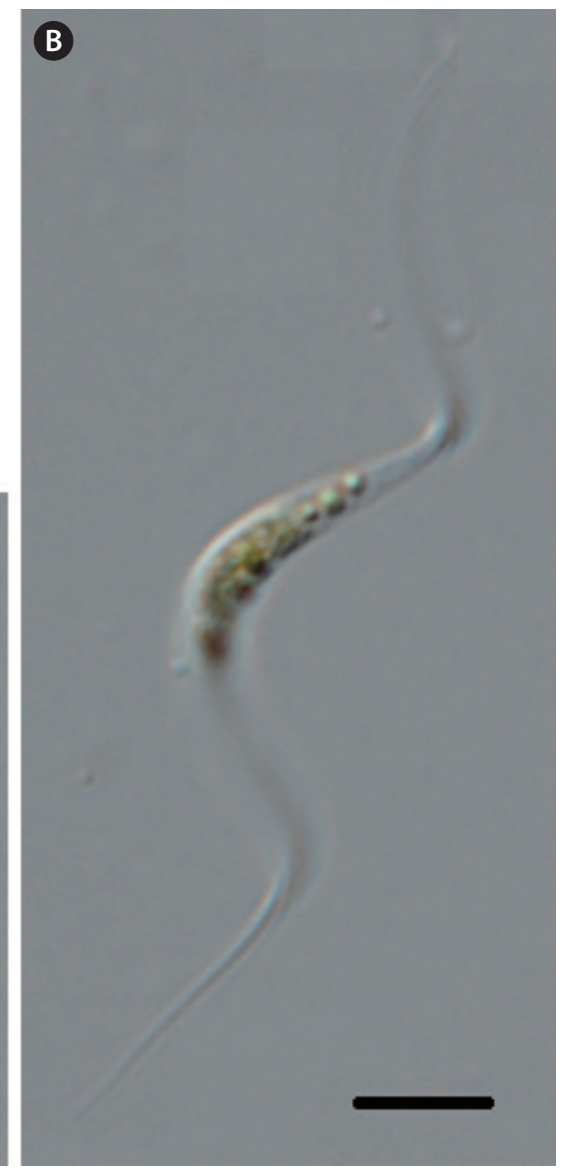

Fig. 9. Schroederia spiralis (Printz) Korshikov (A-B: each other individual). Scale bars, $10 \mu \mathrm{m}$. 

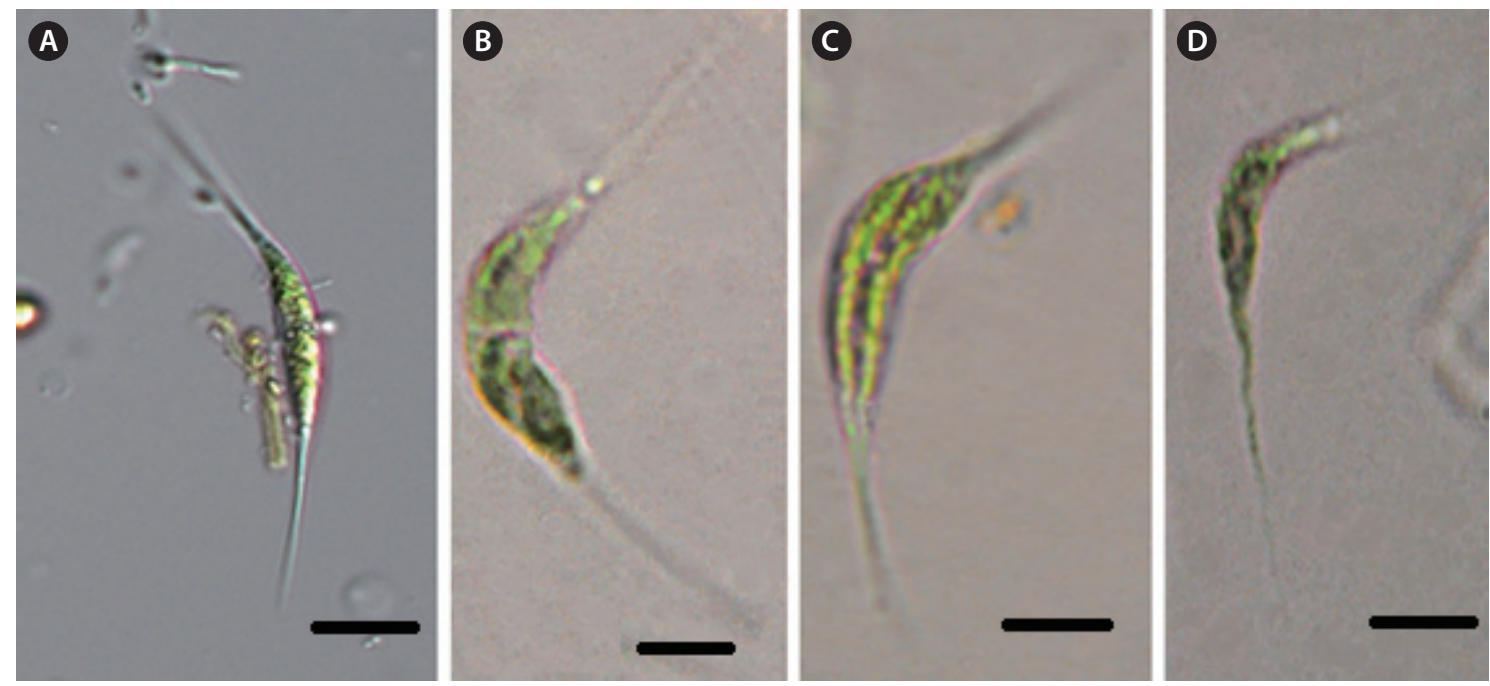

Fig. 10. Schroederia indica Philipose (A-D: each other individual). Scale bars, $10 \mu \mathrm{m}$.

4-12 $\mu \mathrm{m}$ in diameter, and 28-44 $\mu \mathrm{m}$ long.

Information of Collected sites: Lake Seoho (20 Nov 2011: water temp. $8.1^{\circ} \mathrm{C}, \mathrm{pH} 7.9$, TN $2.730 \mathrm{mg} \mathrm{L}^{-1}$, TP 0.055 $\mathrm{mg} \mathrm{L}^{-1}$ ), the Donghwa stream (23 Sep 2011: water temp. $22.9^{\circ} \mathrm{C}$, pH 7.6, TN $7.277 \mathrm{mg} \mathrm{L}^{-1}$, TP $0.050 \mathrm{mg} \mathrm{L}^{-1}$ ), Nammae reservoir (10 Sep 2011: water temp. $28.0^{\circ} \mathrm{C}$, pH 8.4, TN $2.916 \mathrm{mg} \mathrm{L}^{-1}$, TP $0.083 \mathrm{mg} \mathrm{L}^{-1}$ ), Ilweul reservior (03 Sep 2011; water temp. $30.0^{\circ} \mathrm{C}, \mathrm{pH} 8.2$, EC $636 \mu \mathrm{cm}^{-1}$ ), Pond at Samrak park (03 Oct 2011: water temp. $20.0^{\circ} \mathrm{C}$, pH 8.0, TN $2.030 \mathrm{mg} \mathrm{L}^{-1}$, TP $\left.0.112 \mathrm{mg} \mathrm{L}^{-1}\right)$.

Key reference: Philipose (1967).

Remark: The cells of this taxon have regularly curved setae and lie in a plane. However, S. spiralis have the poles extended into long, fine setae, spirally twisted with setae, and S. setigera has the bilaterally straighten setae. Therefore, this taxon differs from S. spiralis and S. setigera by these characters. These authors identify this taxon on the basis of the characters according to Komarek and Fott (1983).

Taxa belonging to these 2 families are cosmopolitan in their distribution (John and Tsarenko 2002, Komarek and Fott 1983, Prescott 1962, Yamagishi and Akiyama 1984, Dillard 1988), and inhabit swamps, ponds, reservoirs, lakes and running waters in Korea (Kim 1994, 1996, Kim and Chung 1993a, 1993b, Kim and Lee 1996). The genus Dictyosphaerium changes the size of colonies and individual cell size according to environmental conditions. Cell shape depends on its age, with young cells elongate or forming narrowly ovoid shapes, and old cells forming widely ellipsoid or spherical shapes (John and Tsarenko
2002). Therefore the effect of age on cells and colonies needs further observation in order to improve species identification. D. pulchellum was reported by Chung (1970) from Hayang, Youngcheon, Gyeongsangbuk-do and Haewondae, Busan. Since then, D. ehrenbergianum was recorded by Chung (1986). However other taxa are not yet reported. 4 taxa (i.e., D. elegans, D. reniforme, $D$. simplex, D. elongatum) of this genus are newly recorded in Korea by this study. These taxa were collected from eutrophic reservoirs and lakes.

The genus Characium of family Characiaceae attached on filamentous green algae (Oedogonoium) or macophytes. Some species of the genus Characium resemble the genus Characiopsis in Xanthophyceae. It was difficult to distinguish the genus Characium and Characiopsis, but was possible to identify these taxa by staining for starch (John and Tsarenko 2002). 6 taxa (i.e. C. ambiguum, C. acuminatum, C. limneticum, C. obtusum, C. pringsheimii, C. rostartum) of this genus were reported by Chung (1970), Chung et al. (1972), Lee (1978) and Kim and Chung (1993b). C. conicum was collected by H.S. Kim on Nov 2011 from the Nakdong river and was newly record in Korea.

The genus Ankyra resembles the planktonic Characium (Hindak 1984), and is closely related to Schroederia and Korshikoviella which it is distinguished by its cell wall dividing into two equal parts too release the zoospores (John and Tsarenko 2002). However, it is distinguished from them by the basal bifid anchor appendages. This genus is cosmopolitan in its distribution and inhabits fishponds, ponds and lakes (Hindak 1984, Komarek and 
Fott 1983). Ankyra paradoxioides of this genus was reported in Korea by Kim et al. (1994), but it is not recorded in this study. 3 taxa (i.e., A. ancora, A. judayi, A. calcarifera), which were collected by H.S. Kim on Oct 2011 in the Nakdong river and pond of Samrak park. Based on Komarek and Fott (1983), I identified taxa of the genus Schroederia. Among them, only 1 taxon (S. setigera) was reported in Korea until now and 2 taxa (S. spiralis, S. indica) are newly recorded in this study.

\section{CONCLUSION}

A total of 20 taxa belonging to 2 families (Botryococcaceae, Characiaceae) are identified in this study. Among them, 10 taxa are newly reported in Algal flora of Korea by Kim and Kim (2012); 1) Family Botryococcaceae : Dictyosphaerium elegans, D. reniforme, D. simplex, D. elongatum, 2) Family Characiaceae : Characium conicum, Ankyra ancora, A. judayi, A. calcarifera, Schroederia spiralis, S. indica. These taxa inhabited from mesotrophic to eutrophic water bodies.

\section{ACKNOWLEDGEMENTS}

This work was supported by a grant from the National Institute of Biological Resources (NIBR), funded by the Ministry of Environment (MOE) of the Republic of Korea (NBIR No. 2013-01-001).

\section{LITERATURE CITED}

Bachmann H. 1913. Planktonproben aus Spanien gesammelt von Prof. Dr. Halbfass. Ber. Deutsch. Bot Ges 31: 183-188. (in German)

Bold HC, Cronquist A, Jeffey C, Johnson LAS, Marguilis L, Merximiller H, Takhtajan AL. 1978. Proposa (10) to substitute the term phylum for division for groups treated as plants. Taxon 27: 121-122.

Bulnheim O. 1859. Die Algen Sachsens. Hedwigia 2: 22.

Chung J. 1970. Taxonomic study on Freshwater Algae in Youngnam area. PhD Dessertation. Kyungpook National University, Daegu, Korea. (in Korean)

Chung J. 1974. A study on the a few species of the freshwater algae in Korea. Kor J Plant Biol 17: 175-177. (in Korean with English abstract)

Chung J. 1978. A Study on freshwater algae in Korea. Korean J Limnol 11: 39-42. (in Korean with English abstract).
Chung J. 1981. Freshwater Algae on Chang-nyeong county area. (Around Bugok hot spring). Bull Kor Assoc Conserv Nat 3: 369-381. (in Korean with English abstract)

Chung J. 1986. Flora of freshwater algae and water quality. In: Conservation of the Gaya ruins and the developmental plan of the natural resources, Gyeongsangbuk-do. Museum of Kyngpook National University, pp 385-453. (in Korean)

Chung J, Kim YJ. 1991. Freshwater algae on Seongju county area. J Kyungpook Natl Univ 51: 33-58. (in Korean with English abstract)

Chung J, Kim HS. 1992. Freshwater algae on Gunwi-county area. J Kyungpook Nat Univ 52: 91-104. (in Korean with English abstract)

Chung J, Kim SD, Lee KS. 1972. Freshwater Algae from Jeju-do Island. Korean J Limnol 5: 15-31. (in Korean with English abstract)

Dillard GE. 1989. Freshwater algae of the southeastern United States. Part 1. Chlorophyceae: Volvocales, Tetrasporales and Chlorococcales. Bibl Phycol 81: 1-202.

Fott B. 1957. Taxonomie drobnohledne flory nasich vod. (Taxanomie der mikroskopischen Flora einheimischer Gewässer). Preslia Praha 29: 278-319. (in German)

Hindak F. 1977. Studies on the Chlorococcal algae. Chlorophyceae, Vol I, Biologické práce 23. VEDA, Bratislava.

Hindak F. 1980. Studies on the Chlorococcal algae. Chlorophyceae, Vol II, Biologické práce 26. VEDA, Bratislava.

Hindak F. 1984. Studies on the Chlorococcal Algae. Chlorophyceae, Vol III, Biologické práce 30. VEDA, Bratislava.

Hindak F. 1988. Studies on the Chlorococcal Algae. Chlorophyceae, Vol IV, Biologické práce 34. VEDA, Bratislava.

Hirose H, Yamagishi T. 1977. Illustration of the Japanese Freshwater Algae. Uchida Rokakuhe, Tokyo, (in Japanese)

John DM. 1994. Alternation of generation in algae: its complexity, maintenance and evolution. Biol Rev 69: 275291.

John DM, Tsarenko PM. 2002. Order Chlorococcales. In: The Freshwater Algal Flora of the Britain Isles: An identification guide to freshwater and terrestrial algae (John DM, Whitton BA, Brook AJ. eds). Cambridge University Press, Cambridge, pp 327-409.

Kawamura T. 1918. Nippon-Tansui-Seibutsugaku (I). Mohanahusa, Tokyo. (in Japanese)

Kim HS, Chung J. 1993a. Freshwater algal flora of natural swamps in Changnyeong county. Korean J Limnol 26: 305-319. (in Korean with English abstract)

Kim HS, Kim YJ, Park JW, Chung J. 1994. Unreported FreshWater algae in Korea. Kor J Plant Biol 37: 131-140. (in Korean with English abstract) 
Kim YJ, Chung J. 1993b. Analysis of phytoplankton community in Lake Imha. Korean J Limnol 26: 175-196. (in Korean with English abstract)

Kim YJ. 1994. The taxonomic and ecological study of phytoplankton in Lake Pomun and Tokdong, South Korea. PhD Dessertation. Kyungpook National University, Daegu, Korea. (in Korean with English abstract)

Kim YJ. 1996. Ecological study of phytoplankton community and trophic states using indicator in Lake Paldang. Korean J Limnol 29: 323-345. (in Korean with English abstract)

Kim YJ, Kim HS. 2012. Algal flora of Korea: Chlorophyta, Chlorophyceae, Chlorococcales I: Micractineaceae, Botryococcaceae, Characiaceae, Hydrodictyaceae. NIBR Ministry of Environment, Incheon.

Kim YJ, Kim HS, Chung J. 1991. Seasonal variation of phytoplankton in Lake Tokdong and Pomun. Korean J Limnol 24: 251-263. (in Korean with English abstract)

Kim YJ, Lee JH.1996. Structure of phytoplankton communities of six Dam lake in the Nakdong river system. Korean J Limnol29: 347-362. (in Korean with English abstract)

Komarek J, Fott B. 1983. Chlorophyceae (Grünalgen) Ordnung: Chlorococcales. In: Das Phytoplankton des Süßwassers. Die Binnengewässer XVI, 7(1) (HuberPestalozzi G. ed). Schweiz Verg, Stuttgart. (in German)

Korshikov OA. 1939. Materialy k poznaniju vodoroslej Gor'kovskoj oblast. Fitoplankton R. Oki v avguste 1932 goda [Contribution to the algal flora of the Gorky district, Phytoplankton of the Oka river in August of 1932]. Ucen Zap Gor'kovsk Gosudarstv Univ Gorkij 9: 101-128. (in Russian)

Korshikov OA. 1953. Pidklas Protokokovi (Protococcinae) Viznaçnik prisnovodnich vodorostej Ukrainskoj RSR. Akad Nauk USSR, Kiev 5: 1-439. (in Russian)

Lee GS. 1978. A study on the Freshwater algae from Eunhae temple and its Neighboring area. Korean J Limnol 11: 49-66. (in Korean with English abstract)

NIER. 2013. Water Information System of the Ministry of Environment. http://water.nier.go.kr.

Philipose MT. 1967. Chlorococcales. Indian Council of Agricultural Research, New Delhi.

Prescott GW. 1962. Algae of the Western Great Lakes Area. Wm C Brown Company Publishers, Dubuque, IA.

Skvortzow BW. 1929. On some diatoms from Seiko lake of Chosen, Japan. J Chosen Nat Hist Soc 8: 9-14.

Smith GM. 1950. The Freshwater Algae of the United States. 2nd ed. McGrew-Hill, New York.

Svirenko DO. 1928. Recherches sur la flore algologique de la riviere Ingouletz (Resume). Arch Russ Protistol Moskov 7: 66-74. (in Russian)

Ueno M. 1940. Limnological survey in North Korea. J Limnol. 11: 96-107. (in Japanese)

Yamagishi T, Akiyama M. 1984-1996. Photomicrographs of the Freshwater Algae. Vol. 1-10. Ukida Rokakuho, Tokyo. 